\title{
1920-1930 Yıllarında Azerbaycan'ın Milli ve Manevi Değerlerine Karşı Sovyet Rusya Tarafından Yürütülen Asimilasyon Siyaseti
}

\section{Ülker Yakar*}

\section{Özet}

Azerbaycan, coğrafi konumu ve sahip olduğu doğal zenginlikleri ile her zaman Rusya'nın dikkatini çekmiştir. XIX. yüzyılın başlarında Çarlık Rusya tarafından işgal edilen Azerbaycan, 28 Mayıs 1918 M.E.Resulzade liderliğinde bağımsızlı̆ını ilan etmiş fakat 27 Nisan 1920 yılında tekrar Bolşevik Rusya tarafından işgal edilmiştir. 1991 yılına kadar süren bu işgal Azerbaycan Türkleri üzerinde büyük yıkıma neden olmuştur. Azerbaycan'a tamamen hâkim olmak isteyen Sovyet Rusya, çıkarlarına hizmet eden nesiller yetiştirmeyi, halkı İslam ve Türk kültüründen koparıp Sovyet kültür potası içerisinde eritmeyi hedeflemiştir. Bu çerçevede sosyal ve kültürel alanlarda izlenilen politikalarla Azerbaycan halkı kendi kimliklerinden kopartılmak istenmiştir. Bu çerçevede halkın inanç özgürlüğü kısıtlanmış, 1938'e kadar kimliğinde "Türk" yazan halkın nüfus cüzdanına "Azerbaycanlı" yazmak zorunlu hale getirilmiş Azerbaycan Türkçesi yok sayılarak alfabe değişikliğine gidilmiş, Rusçanın eğitim dili olarak zorunlu hale getirilmesiyle halkın anadili unutturulmak istenmiştir. Rusya'nın asimilasyon politikası toplumun temeli olan aile içi ilişkiler, halkın giyim kuşamı, sanat alanında da kendisini göstermiş, tar, kemençe, zurna, balaban gibi müzik aletlerinin çalınması dahi yasaklanmıştır. Azerbaycan halkında güvensizlik ve nefret duyguları uyandıran bu müdahaleci politikaların halk isyanlarına yol açmaması için Sovyet rejimi tüm bu politikaları "reform" adı altında uygulamıştır. Bu çalışmanın konusu olan Sovyet Rusya'nın Azerbaycan'da milli ve manevi alanda yaptığı sömürge faaliyetleri çalışılırken; eğitimden dil, kültür, aile yaşantısı gibi sosyal alanlar da dâhil olmak üzere tüm alanlarda Sovyet Rusya tarafından Azerbaycan Türklerine uygulanan asimilasyon politikaları arşiv vesikaları ve konu ile ilgili bilimsel çalışmalar incelenerek hazırlanmıştır.

Anahtar Kelimeler: Sovyet Rusya, Azerbaycan, Sömürge Politikası, Milli ve Manevi Değerler

\footnotetext{
* Yüksek Lisans Öğrencisi, Sakarya Üniversitesi, Sosyal Bilimler Enstitüsü, Tarih ABD, Yakınçağ Tarihi Bilim Dalı, ulkeryakar@hotmail.com. (Makale Gönderim Tarihi: 21.02.2018; Makale Kabul Tarihi: 15.04.2018) (ORCID ID: 0000-0001-6112-4304).
}

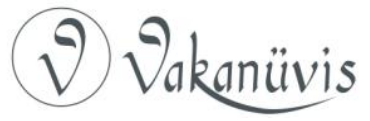




\section{Assimilation Policy Carried out by Soviet Russia Against Azerbaijan's National and Moral Values Between the Years 1920-1930}

\section{Abstract}

Azerbaijan, with its geographical position and natural richness, has always attracted Russia's interest. Azerbaijan, having been invaded by Russia in the early XIXth century, declared its independence on 28 May 1918 in the leadership of M.E. Resulzade but was invaded by Bolshevik Russia again on 27 April 1920. This invasion, which lasted until 1991, caused a great destruction among Azerbaijani Turks. Soviet Russia, who wanted complete command of Azerbaijan, intended to raise new generations that served Soviet Russia's purpose to remove the community from Turkish culture and Islam, and to impose Soviet culture. Through social and cultural policies, Azerbaijan society was broken its identity. In this aim, freedom of religion was restricted and it was necessary to write Azerbaijani on the IDs instead of Turk until 1983. With a similar assimilation policy, Azeri Turkish was ignored and the alphabet was changed, in order to make Russian the language of education and to make Turkish forgotten. This assimilation policy showed its effects in familial relationships, clothing of public and art and even playing tar, fiddle, clarion, balaban was banned. In order for these intrusive policies to not cause a riot, Soviet regime carried out these policies as "reform". In this study, while Soviet Russia's national and moral exploitation acts in Azerbaijan were examined. Education language, culture and family life were taken into account through archival documents and scientific works related to the topic

Keywords: Soviet Russia, National Values, Azeri Turkish, Colonial Politics, , Alphabet Reform

\section{Giriş}

Azerbaycan Cumhuriyeti Kafkasların geçiş noktası üzerinde, Büyük Kafkaslar ile Küçük Kafkaslar arasında yer alan bir ülkedir. Güney Kafkasya'nın en büyük yüzölçümüne sahip ülkesi olan Azerbaycan’ın doğusunda Hazar Denizi, kuzeyinde Gürcistan ile Rusya Federasyonu'na bağlı Dağıstan Özerk Cumhuriyeti, batısında Ermenistan ve Türkiye Cumhuriyeti yer almaktadır. Azerbaycan'ın iklim özellikleri, Kafkas coğrafyasından İran'a, Türkiye'ye ve diğer ülkelere geçiş yollarının üzerinde bulunması, bu ülkeye daha büyük bir stratejik önem kazandırmıştır. Ülkenin coğrafi konum bakımından stratejik değerinin yanında tarım, hayvancılık yönüyle de zengin topraklara sahip olması onu daha cazip hale getirmiştir. Sahip olduğu gaz ve petrol rezervleri

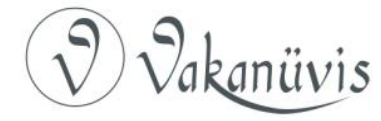


Azerbaycan'ı Rusların gözünde vazgeçilmez kılmıştır.

Sanayi devrimi ile birlikte gelişme gösteren Rusya'nın doğuya doğru yayılma politikası, Rusya-İran savaşının başlamasına neden olmuş, 1826-1828 yılları arasında yapılan savaş, $1828^{\prime}$ de imzalanan Türkmençay antlaşması ile son bulmuştu. Bu antlaşma gereğince Azerbaycan, Kuzey Azerbaycan ve Güney Azerbaycan (İran Azerbaycan'ı) olmak üzere ikiye ayrılmış, Rus-ïran sınırı Aras Nehri olarak çizilmiş, Kuzey Azerbaycan Rusya'ya geçmiştir. Bu süreçten sonra Rusların Azerbaycan'da yayılma ve sömürge politikası başlamış, Azerbaycan halkı ağır Rus baskısı altında ezilmiştir.

XX. asırda Rusya'da sanayinin belli bir noktaya gelmesine rağmen, sosyal bünyedeki ve gelir dağılımındaki dengesizlikten dolayı, çeşitli fikir akımlarının etkisiyle, 1917 Ekim İhtilali gerçekleşmiş, V.í. Lenin'in başkanlık ettiği ihtilalle İmparatorluğun yönetiminde söz sahibi olan Romanov ailesi ortadan kaldırılmıştır. ${ }^{1}$ Bu olay neticesinde Rus Ihtilali'ni fırsat bilen Azerbaycan aydınları, 28 Mayıs 1918'de Çarlık Rusya'nın sömürüsü olan Kuzey Azerbaycan'da bağımsız Azerbaycan

Halk Cumhuriyeti'ni kurmuştur. Fakat Bolşevik baskısına uzun süre karşı koyamayan genç cumhuriyet, sadece 18 ay varlığını sürdürebilmiş, 20 Nisan 1920 yılında XI. Kızıl Ordu'ya teslim olmak zorunda kalmıştı.

Bolşevik İhtilali'nin ilk günlerinde, gizli planlarının ortaya çıkmasından endişelenen, Bolşeviklere Rusya dışında da destek arayan Lenin, eşitlik ilkesi üzerinde durmuş, Rus Çarlığı döneminde esaret altında bulunan milletlere bağımsızlık vaadinde bulunmuştur. Ama bu bağımsızlık vaatleri ve Çarlık Rusya'sını suçlama oyunları, sadece göz boyamak, vakit kazanmak için oynanmış, hiçbir zaman gerçeği yansıtmamıştır. Başlangıçta Sovyet Rusya'sı Çarlık Rusya'sının mirasını reddetmişse de aslında uygulamada bu hiç de böyle olmamıştır. Kendini toparlamaya çalışan komünist Rusya vakit kaybetmeden Çarlık Rusya'nın asimilasyon politikasını kaldığı yerden uygulamaya devam etmiştir.

1920- 1930'lu yıllarda Azerbaycan'da çok karmaşık siyasi ve

\footnotetext{
${ }^{1}$ Yasin Aslan, Üçüncü Roma'nın Jeopolitik Arzuları, Avrasya Uluslararası Iilişkiler ve Araştırma Merkezi, Ankara, 1996, s. 3.
}

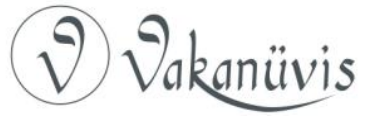


toplumsal olaylar yaşanmış, Sovyet idari amirlik sisteminin oluştuğu bu yıllar, ülke tarihinde derin yaralar açmıştır. Toplumsal hayatın tüm alanlarına müdahale eden devlet, tekelci bürokratik özellik taşıyarak sadece merkezden emirlerle idare etme yöntemini benimsemişti. Ülkede tek legal partinin faaliyet göstermesi Sovyet siyasi sisteminin esas özelliklerinden biriydi. Komünist Parti'nin önderlik edici rolü tüm devlet alanlarına nüfuz etmişti. Marksizm ideolojisinin güçlü propagandasına rağmen, Bolşevizm Azerbaycan'da yeteri kadar manevi ve sosyal destek bulamamıştı. Dini inançlara, kültürel değerlere karşı yapılan hamleler, halkta Sovyet hükûmetine karşı güvensizlik ve nefret duyguları uyandırmaya başlamıştı. Halk direnişinden korkan Sovyet yönetimi ise, "tüm alanlarda devrim" adı altında daha kurnazca bir politika uygulama yoluna başvurmuştu. ${ }^{2}$

Sovyet Rusya'nın ekonomik ve politik alanlarda yürüttüğü asimilasyon politikası, kültürel alana da yansımıştı. Sovyet rejimi, ilk olarak tarihi köklere sahip milletin, bağımsızlığının temeli olan Azerbaycan Türkçesine karşı baskı uygulamaya başlamıştı. Rusça eğitim dili olarak zorunlu kılınmış, Azerbaycan halkının kendi kültürü ile olan bağları kopartılmaya çalışılmıştı. Ancak birçok Azerbaycan aydını Sovyet yönetiminin gerçek amacının farkına vararak buna karşı koymaya çalışmıştır. Bu çerçevede 1923 yılında düzenlenen XII. Umumbakü parti konferansında L.Mirzoyan, R.Ahundov, M.D.Hüseyinov, E.H.Garayev ve S.Orconikidze'nin konuşmalarından sonra resmi dil konusunda Azerbaycan Türkçesini savunan R.Ahundov ${ }^{3}$ tarafından teklif olunan 9 bölümden oluşan "Milli Mesele Hakkında Karar" kabul edilmiştir. Kararın Devlet Dili adlı bölümünde "Devlet daireleri gerçek anlamda millîleşmedikçe (dil yönünden) Sovyet iş̧̧i sendikalarının ve Sovyet ekonomi kuruluşlarının yerli emekçilerle yakınlaşması ve onların Sovyet idari rejimine dahil edilmesi mümkün olmayacaktır" 4 ifadeleri yer

\footnotetext{
2 Azerbaycan Milli Elimler Akademiyası (AMEA), A. Bakıhanov adına Tarih İnistitutu, Azerbaycan Tarihi, (aprel 1920-iyun 1941), Bakı, Elm, 2008, s. 221.

31924-1930'lu yıllarda Azerbaycan KP(b) MK'nin katibi, Azerneşir direktörü, 19271930 yıllarında Azerbaycan Halk Maarifi komiseri görevlerinde bulunmuştur. 1938 yılında tüm görevlerinden uzaklaştırılarak, KP üyeliğinden çıkartılarak hapsedilmiş, Yüksek Askeri Mahkeme Şurası kararı ile kurşuna dizilerek KGB'nin gizli poligonu olan "Kommunarka-Loza"da gömülmüştür. Stalin'nin ölümünden sonra 1959 yılında beraatına karar verilmiş ve parti üyeliği hakkı iade edilmiştir.

${ }^{4}$ M.B. Memmedzade,Köylü Herekatı. Lenin Milli Siyaseti. Bakı,2007, s. 97.
}

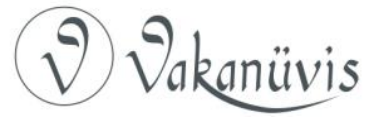


almasına karşın, Sovyet yönetimi bu tür teklifleri görmezden gelerek ciddiye almamıştı.

Aslında 1923 yılına dek Azerbaycan sınırları içinde kullanılan resmî dilin Azerbaycan Türkçesi olması ile ilgili birçok karar ve teklif ileri sürülmüş fakat hiçbir sonuç alınamamıştı. Çünkü Moskova'nın gözünde Azerbaycan'ın önemi ve değeri sadece Doğu'yu Bolşevikleştirmekten ibaret değildi. Azerbaycan, petrol, pamuk, yün, demir, bakır, tuz gibi zengin maden kaynakları ile Moskova ekonomisi için önemli bir gelir merkezi görevini görüyordu. Moskova bu fırsatı kaçırmak istemiyor, Azerbaycan'ı ekonomik anlamda sömürmek için onu güçlü Rus ordusu işgali altında tutma amacı güdüyordu. Moskova yönetimi, planlarını hayata geçirmek için tüm askeri, ekonomik ve siyasi gücü elinde bulundurmayı hedefliyor ve bu çerçevede idari alanda da bu amacına hizmet eden daire ve kuruluşların da merkeze bağlı olmasını istiyordu. Bu yüzden de merkez Azerbaycan'ın Türkleşmesine fırsat vermiyordu. ${ }^{5}$

1920'li yıllarda Azerbaycan aydınları arasında zaman zaman oluşan fikir ayrılıkları, Sovyet rejiminin uygulamalarını kolaylaştırıyordu. Örneğin, dil meselesinde yerli komünistler fikir ayrılığına düşmüşlerdi. AK (b) P MK'nin (Azerbaycan Komünist (Bolşevik) Partisi) 1927' de düzenlenen VIII. Kurultayında konuşan Ruhulla Ahundov Türkçenin Anadolu lehçesinin Azerbaycan Türkçesine yakın olması sebebi ile bazı Türkçe kelimelerin kullanılmasının mümkün olabileceğine değiniyordu. Fakat Müseyip Şahbazov, Teymur Hüseyinov gibi bazı katılımcılar bu fikrin bazı aydınlar ve Türkçe konuşanlar tarafından yanlış anlaşılacağını dile getirerek; "Onlar bize siz Osmanlı lehçesine karşıydınız, şimdi ise bu dilden kelimeler iktibas ediyorsunuz derler. Bu yüzden meseleye taktik yönünden farklı yaklaşmak gerekiyor. Yani Anadolu lehçesini resmileştirmeden pratik hayatta kullanmak gerekiyor" şeklinde itiraz ediyorlardı. ${ }^{6}$ Akıbeti ile ilgili endişeleri olan R.Ahundov haklı olarak teklifinde Israr etmiyor, "Kemalist", "Türk meyilli" gibi isimlerle damgalanmaktan korkuyordu. Çünkü o zamanlar ileri sürülen tüm fikirlerde Sovyet karşıtı özellikler aranıyordu.

1920 'li yılların en önemli olaylarından biri Arap alfabesinden Latin

\footnotetext{
${ }^{5}$ Memmedzade a.g.e., s. 101.

${ }^{6}$ VIII. Siyezd Azerbaydjanskoy Kommunistiçeskoy Parti.12-18.XI.1927 g.
}

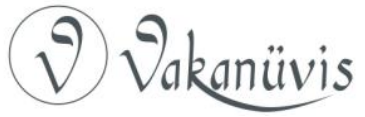


alfabesine geçiş ile ilgili yapılan reformdu. Daha Azerbaycan Demokratik Cumhuriyeti (1918-1920) döneminde alfabe sorunu gündeme getirilerek Arap alfabesinin tashihi, geliştirilmesi veya yeni Latin esaslı alfabeye geçilmesi "Azerbaycan" gazetesinde tartışmaya açılmıştı. Aynı müzakerelerin devamı olarak 1920'de S.M.Ganizade, H. Şahtahtlı, V. Tomaşevski ve millî şair Hüseyin Cavit'ten oluşan yeni alfabe komisyonu oluşturulmuştu. Komisyona Fransız Türkolog P. Juze başkanlık ediyordu. 1922 'de SSCB'nin oluşmasından sonra Slavlar ve Müslümanlar arasında ilişki ve kültürel etkileşimin oluşturulması meselesi ortaya çıkmıştı. 1922'de Rus olmayan halkların alfabelerinin (her şeyden önce Arap alfabesi kullanan Türk dilli halkların ) Latin alfabesi ile değiştirilmesi fikri ileri sürüldü. Yapılan müzakereler sonucunda Arap alfabesinden kurtulma kararı alınmıştı. Sovyet Rusya'nın "büyük devletçilik ve milliyetçiliğe karşı" propaganda kampanyası yaptığı bir devirde alternatif olarak Kiril alfabesini teklif etmeyi düşünmesi sakıncalı olacağından Latin alfabesi üzerinde durulmuştu.

Nisan 1922'de "Yeni Türk alfabesi" komitesi oluşturulmuş, komite, Türkistan'a, Tatar, Hive ve Kırım hükümetlerine yeni alfabe projesini göndererek "onlardan hem yeni alfabe projesine, hem de Arap alfabesinin Latin alfabesi ile değiştirilmesi fikrine görüş bildirmeleri" ricasında bulunmuştu. ${ }^{7}$

20 Ekim 1923 tarihinde Azerbaycan Sovyet hükûmeti "Yeni Türk alfabesinin devlet alfabesi olarak kabul edilmesi" ile ilgili kararını ilan etmesinin ${ }^{8}$ ardından 16 Mart 1925'te Bakü'de düzenlenen Azerbaycan Sovyetler Kurultayı'nın kararı ile ilkokullarda Latin alfabesine geçilmişti. Bu kurultayın bilimsel , siyasî, malî ve diğer hazırlık planları tüm detayları ile Moskova'da hazırlanmıştı.

Görüldüğü gibi Sovyet hükûmeti daha 1920'li yılların başında keşif karakterli faaliyetler yaparak Latin alfabesi propagandası yapmış, Arap alfabesini hedef seçerek daha sonra Azerbaycan'a dayatacağı Kiril alfabesinin önünü açmaya çalışmıştır. Kabul edilen ve hayata geçirilmeye çalışılan kanunlarla yetinmeyen Moskova, 1926 yılında

\footnotetext{
${ }^{7}$ AMEA, a.g. e. s. 228.

${ }^{8} 1926$ Yılı I. Bakı Türkoloji Kurultayı, Bakı, “Çinar-Çap” Neşriyyatı, 2006, s. 455
}

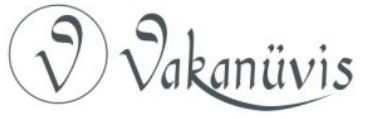


Türk dilli milletler açısından da büyük önem arz eden Türkoloji kurultayını organize etmişti. ${ }^{9}$ Şüphesiz ki Moskova yönetimi bu kurultayı düzenleyerek, başta i.V.Stalin olmakla birlikte komünistlerin gizli maksadı olan Türkiye ve Türkçülüğe karşı hücum planlarını belirlemek ve Türklerin meskûn olduğu bölgeleri komünistleştirmek amacı güdüyordu. Moskova için Türkçü düşünce ve siyasetin bilimsel açıdan öğrenilmesi gelecek için büyük önem taşıdığından kurultayın düzenlenmesi boşuna değildi. Daha sonraları yani 1920'li yılların sonları ve 1930'lu yıllarda Sovyet terörüne uğrayan, hapislerde çürüyen Türkologların birçoğu 1926 yılı I. Bakü Türkoloji kurultayı katılımcılarıydı. ${ }^{10}$

I. Türkoloji kurultayı 26 Şubat-6 Mart 1926 tarihleri arasında Bakü'de düzenlenmiş, kurultaya $\mathrm{SSCB}^{\prime}$ de yaşayan ve yurtdışından davet edilen 131 önemli bilim adamı katılmıştır. 9 gün süren kurultay sırasında 17 toplantı düzenlemiş, Türk dünyasının diline, tarihine, etnik ve etnografik tarihine, edebiyatına dair 38 konuşma metni dinlenmiştir. Kurultay esnasında Türk dilinin 7 büyük sorunu ele alınmıştır:

1. Alfabe sorunu

2.Yazım sorunu

3.Termin sorunları

4.Öğretim yöntemleri

5.Akraba ve komşu dillerin karşılıklı ilişkileri

6.Edebî dil ve ortak edebî dil sorunu

7.Kök dil teorisi ve Türk dilinin tarihi sorunları esas tartışma mevzusu olmuştur.

Türkoloji kurultayının kabul ettiği kararlar arasında ortak alfabe ortak edebî dil, ortak terminoloji gibi önemli meseleler de yer almıştır. Büyük Türkolog Ali Bey Hüseyinzade fahri üye olarak kurultaya davet edilmiş, ünlü Türkologlar İsmail Bey Gaspralı ve V.Radlov'un şeref konuğu olduğu kurultaya Fuat Köprülüzade, A.E.Krımski, N.N.Poppe,

${ }^{9}$ G.V. Kostırçenko, Taynaya politika Stalina: Vlast i Antisemitizim, İzd. 2-e, Moskova, Mejdunarodnıye otnoşeniya, 2003. s. 164-165.

${ }^{10} 1926$ Yılı I. Bakı Türkoloji Kurultayı, s. 451.

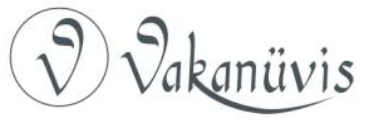


B.Çobanzade gibi tanınmış isimler de katılmıştır. 6 Mart'ta biten kurultayda bir dahaki kurultayın Semerkand'da yapılmasına karar verilmiştir. Ancak ne yazık ki 2. kurultayın yapılması mümkün olmamış, Bolşevik rejimi; ı. Bakü Kurultayı katılımcılarına karşı uyguladığı baskı ile birçok katılımcıyı ortadan kaldırmayı başarmıştı.

UK(b) P MK'nin (Umumittifak Komünist (Bolşevik) Partisi Merkezî Komitesi) teşkilat bürosunun 1927 yılında yapılan toplantısında, Yeni Türk alfabesini uygulamak üzere Umum İttifak Komitesi oluşturulmuştu. Bu komitenin Moskova'da temsilciliğinin olması şartı ile Bakü'de kurulmasına karar verilerek Komite başkanlığına S. Ağamalıoğlu ${ }^{11}$ getirilmişti. Nihayet Aralık 1928'de, 1 Ocak 1929 yılından itibaren Azerbaycan'da Yeni Türk alfabesine geçilmesine karar verilmişti. ${ }^{12}$ Rusya, yeni alfabenin Arap alfabesi kullanan diğer Türk halkları tarafından da ortak kullanımını amaçlamış fakat bu süreç uzamıştı. S. Ağamalıoğlu, bunu kendi dilleri olan ve kültürel alanda Azerbaycan Türklerinden geri kalan diğer halklara bağlıyordu. S.Ağamalıoğlu alfabe meselesinin bir an önce halledilmesinin gerektiğini "Ortak alfabenin kabulü bu halklar için öğrenmeyi kolaylaştıran, medeniyetlerin kavuşmasını ve birbirinden etkilenmesini sağlayan şarttır"13 sözleriyle ifade etmiştir.

Oluşturulan Merkezî Komite, ilgili tarafları ikna etmeye çalışarak Türk dilli cumhuriyetlerde ortak kullanım şekline sokulmuş alfabeyi kabul ettirmeyi başarmıştı. Yeni alfabe Türkmenistan, Tacikistan, Dungan, Özbekistan, Kazakistan, Kırgizistan, Tataristan, Dağıstan, Kuzey Kafkasya diyarı (Osetya, İnguşetya, Kabardalılar, Çeçenler, Karaçaylar, Kumuklar) ve Abhazya halkları tarafından da kullanılmaya başlanmıştı.

\footnotetext{
${ }^{11}$ Samet Ağa Ağamalıŏlu ( 27 Aralık 1867 - 6 Ekim 1930) Sovyet devlet adamı ve sosyalist devrimci. Latin alfabesinin Doğu Sovyetlere girmesine öncülük etti. Ağamalıoğlu ayrıca devrimci hareket ve Sovyetler Birliği'nin doğu bölgelerinde kültür devrimi üzerine birçok çalışmanın yazarıdır. Dönemin kültürel ikonu Maksim Gorki, onu "olağanüstü adam" olarak tanımlamıştır ve yeniden düzenlenmiş alfabe üzerine çalışmalarını çok takdir etmiştir.

${ }^{12}$ Azerbaycan Respublikası Prezidentinin Işsler Idaresi Siyasi Senedler Arxivi, f. 1, siy. 74, iş. $285, \mathrm{v} .32$.

${ }^{13}$ ARPIi SSA, F. 1, SiY. 74, iş. 282, V. 138.
}

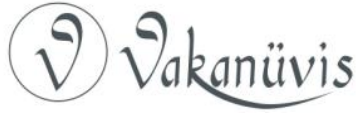


Ancak bununla beraber, Azerbaycan yeni alfabeyi kabul etmek istememiş, ülkede ortak alfabeye geçme süreci uzamıştır. ${ }^{14}$

Nihayet Mayıs 1932 yılında AK(b) P MK bürosunun verdiği karara göre Umum İttifak Komitesinin emrine esasen kesin olarak 1 Haziran 1932 tarihinden itibaren Azerbaycan'da da ortak kullanım şekline sokulmuş ve Latinize edilmiş alfabeye geçilmiştir. ${ }^{15}$ Ancak yeni alfabeye geçiş plansız, alt yapı çalışması olmadan yapılmış ve bu da bazı sorunlara yol açmıştı. Latin alfabesini bilenlerin sayısı az olduğu için süreç çok yavaş ilerliyor hatta reformun esas teşebbüsçülerinden sayılan S.Ağamalıoğlu da yeni alfabeyi tam olarak bilmiyordu. ${ }^{16}$ Öğretmen kadrolarının hazırlanması, matbaaların yeniden düzenlenmesi için para yetmemişti. Elbette ki Latin alfabesinin teknik yönden bazı üstünlüklerini inkar etmek mümkün değildir. Fakat UK(b) $P$ MK'ni bunların hiçbiri ilgilendirmemişti.

Aslında Arap alfabesini hedef alan Komünist Partisi'nin esas amacını din ve din adamları ile mücadele teşkil ediyordu. Bunu M.S. Efendiyev'in 4 Mart 1926 tarihli I. Türkoloji Kurultayı'nın 12. toplantısında yaptığı konuşmasındaki şu ifadelerinden anlamak mümkündü: "Latin alfabesinin kabulü bizi, daima geri kalmamıza neden olan klerikalizmden kurtaracaktır. Bizim kullandığımız Arap alfabesi, din ve din adamlarının kapitalizm ile birlikte kitlelerin şuuruna yıkıcı etki gösteren gücün hükümran olması ile ilişkilidir. Avrupa kapitalistleri bizi fiziki yönden istismar ediyor, din adamları ise şuurumuzu zorluyorlar. Latin alfabesinin kabulü bizi din adamlarının istismarından kurtarır ve kültürel alandaki başarılarımız için zemin hazırlamış olur. ${ }^{17}$ Fakat bu şekilde Azerbaycan'ın, başına nasıl büyük sorun aldığını tahayyül dahi edemiyordu. O dönemden kalan bazı belgelerde de Arap alfabesi haksız bir şekilde, "köhne toplumun mülteci alfabesi" gibi değerlendirilmiş ve herhangi bir sebepten dolayı reforma karşı çıkan aydınlar ise cehaletlerini saklamak için Arap alfabesini savunmakla suçlanmıştır. ${ }^{18}$ Aslında oynanan tüm bu alfabe

\footnotetext{
${ }^{14}$ ARPii SSA, F. 1, SiY. 74, iş. 282, V. 138.

${ }^{15}$ ARPii SSA, f.1, siy.74, iş 321, v. 106 - 107.

${ }^{16} 1926$ Yılı I. Bakı Türkoloji Kurultayı, s. 259.

${ }^{17}$ B, Refiyev , Aysbergin Sualtı Hissesi, Bakı, Azerneşr, 1995, s. 48.

${ }^{18}$ C. Hesenov, Ağ Lekelerin Gara Kölgesi, Bakı,"Gençlik", 1991, s. 139.
}

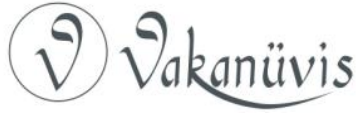


oyununun amacı Sovyet Rusya ile Türkiye ilişkilerini bozmak, Azerbaycan-Türkiye yakınlaşmasının önünü kesmekti. Sovyet Rusya Latin alfabesini kabul ettirmekle Türkleri o zamanlar, Osmanlı alfabesi kullanan Türkiye'den uzaklaştırmayı, Türkleri birbirinden koparma geleneğinin temellerini atmayı amaçlamıştı. ${ }^{19}$

Latin alfabesinin Kuzey Azerbaycan ve İran Azerbaycan'ında yaşayan, Arap alfabesi kullanan kardeşleri ayıracağı fikrini savunanlar da vardı. Lakin Moskova bu düşünceye karşı gelerek Latin alfabesine geçmekle sakıncalı kültür ve ideolojilerin Sovyet Müslümanlarına "zararlı etkisinin" tedbiri alınmaktadır ${ }^{20}$ tezini savunuyordu. Tabi ki gerçek amacını, kardeş olan Azerbaycan ve İran Türklerini birbirinden koparma, ayırma olduğunu saklamaktaydı.

Tüm bu tartışmalara rağmen Latin alfabesi kullanımının ömrü çok uzun sürmemişti. Gereken ortamın oluştuğundan emin olan Stalin ve Molotov bu alfabeye karşı çıkmaya başlamıştı. 15 Mayıs 1936 yılında Merkezi Komite'nin Bilim, Bilimsel Teknik İcraatlar ve Keşifler şubesi müdürü K.Y.Bauman, MK'nin (Merkezi Komite) katipleri A.A.Andreyev ve N.i.Yejov'a yazdığı mektubunda $M K$ ve onu yerli organlarını "Latinleştirmeyi mutlak prensibe çevirmekle", Halk Maarif Komiserliği'ni ise " Latin alfabesinin uluslararası öneminden bahsederek aslında Batı'nın burjuva kültürüne doğru yol almakla" suçluyordu. ${ }^{21} 2$ Temmuz 1937 yılında Siyasi büro MK'yi feshetmişti. Bu tarihten itibaren Türk dilli cumhuriyet ve özerk cumhuriyetlerde Latin alfabesinin yerini Kiril alfabesi almaya başlamıştır. Latin Alfabesine geçişi öve öve bitiremeyen bazı Azerbaycan aydınları, kısa bir süre sonra karşılarına çıkacak Rus oyununun farkında bile değillerdi. Azerbaycan'da bu değişiklik 1939 yılının ortalarında ortaya çıkmış ve Moskova gerçek yüzünü göstermeye başlamıştı. ${ }^{22}$ Alfabe değişikliği ile yetinmeyen Moskova, SSCB halklarının birleşmesinde Rus dilinin önemini abartarak, 1 Eylül 1938 yılından itibaren Rusça dersini "milli cumhuriyet ve özerk vilayetlerin okullarında eğitim dersi" olarak ilkokul 2. ve 3. sınıfların müfredatına dahil etmişti. Rus dilinin eğitimi ile ilgili

\footnotetext{
${ }^{19}$ Hesenov, a.g.e., s.139.

${ }^{20}$ Refiyev, a.g.e., s. 49.

${ }^{21}$ Kostırçenko, a.g.e., s. 166.

${ }^{22}$ Kostırçenko,a.g.e., s. 168.
}

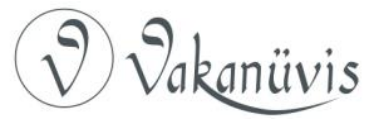


SSCB HKS'i (Sovyet Sosyalist Cumhuriyetler Birliği Halk Komiserleri Sovyeti) ve UK(b) P MK'nin kararı yayımlanmış ve bunun neticesinde ${ }^{23}$ Rus dilinde eğitim veren okul sayısının çoğaltılmasına başlanmıştı. Bu tür okulların çoğaltılmasının iki amacı vardı: İlk neden, Rusya dışındaki cumhuriyetlerde yaşayan Rus nüfusun işini kolaylaştırmak; ikinci neden ise çocuklarının geleceğine dair önemli planları olan anne ve babalarda, evlatlarının "imparatorluk" dilini öğrenerek önemli yerlere gelebilecekleri, Rus dilli okullarda okumayan diğer vatandaşlardan üstün olabilecekleri fikrini uyandırmaktı. ${ }^{24}$

Rus dilini hâkim kılmaya çalışan ve bununla yetinmeyen Moskova, müdahaleci yüzünü her fırsatta göstermiştir. Örneğin, Azerbaycan'da faaliyet gösteren kurum ve teşkilatların yerlileştirilmesi meselesi gündeme getirilirken, çalışanların Azerbaycan Türklerinden temin edilmesinden daha çok milliyetine bağlı olmayan yerel dil bilen şahıslar arasından seçilmesi teklif etmişti. Azerbaycan Türklerinden oluşan kadroların iş başına getirilmesini talep eden komünistlere ise "milliyetçi" damgası vuruluyordu. Devlet dairelerinde yerel dillerin mecburi kullanımı yasaklanıyor, istisnasız tüm il ve ilçelerdeki resmi yazışmalar Rus dilinde yapılıyor bu da köylerde çalışan, Rusça bilmeyen ahalinin işini zorlaştırıyordu. ${ }^{25}$

Moskova, Azerbaycan'da uyguladığı alfabe ve dil alanındaki baskılarla yetinmeyerek İslamiyet'le ilgili de baskıcı politikalar uygulamıştır. Ancak 1920'li yılların başları ile mukayese edildiğinde aynı yılın ortalarında daha sert uygulamalar göze çarpmaktadır. Bu çerçevede AK (b) P MK'nin Şubat 1923 tarihli toplantısında din aleyhine propaganda faaliyetlerini güçlendirme kararı alınmış, Ağustos 1924 yılında Bakü parti komitesi Bakü'de "Allahsızlar Cemiyeti" kurulması ile ilgili kararı kabul etmişti. ${ }^{26}$ Bu cemiyetin 1928 yılından itibaren köylere baskısı daha da arttı. Aynı cemiyet daha sonra "Mücadeleci Allahsızlar İttifakı"na dönüştürüldü. Gazete sayfalarında "Mollalar, sosyalizmin acımasız düşmanıdır", "Keşişler faşist ajanlarıdır"27 gibi başlıklı yazılara

\footnotetext{
${ }^{23}$ Kostırçenko,a.g.e., s. 168.

${ }^{24}$ Hosking, a.g.e., s. 236.

${ }^{25}$ Hosking, a.g.e., s. 236-237.

${ }^{26}$ Refiyev, a.g.e., s. 382.
}

27 Nuru Zeynalabdin oğlu Memmedov, Azerbaycan Dövletçiliyi Tarixinde Azerbaycan Merkezi İcraiyye Komitesinin Yeri ve Rolu (1921-1938-ci iller), Bakı,

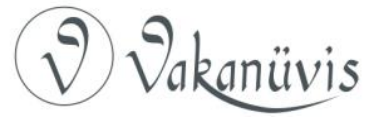


sıkça rastlanıyordu. Fakat "Allahsızlar Cemiyeti" halkın desteğini kazanamamıştı. Hatta halkın gazabına uğramış, ${ }^{28}$ mescitleri toplantı salonlarına çevirmeye çalışan ateistlere karşı Guba, Akdam, Salyan, Şamahı, Bakü, Göyçay ve Nahçıvan'da geniş halk ayaklanması başlamış ve ateistlere "darbe" vurulmuştur. ${ }^{29}$

Devlet tarafından Kuran-ı Kerim zararlı kitap ilan edilerek yasaklanmış, mescitlerin birçoğu kapatılmış, tüm SSCB genelinde 1912 yılında faaliyet gösteren 26.279 mescitten, 1942 yılında sadece 1.312'si ayakta kalabilmişti. $^{30} 1928$ yılının sonbaharında Şamahı şehrindeki 16 mescitten 13'ü yıktırılmış, 1929 yılının Mart ayına dek Göyçay kazasında 147 mescidin faaliyeti sonlandırılarak, mescitler ambara, kültür merkezine, okula ve kulübe dönüştürülmüştür. Sadece 1929 yılında Azerbaycan'da 400 mescit kapatılmıştı. ${ }^{31}$

Parti kanalı ile yazılan bir yazıda;"Sadece 1929 yılının başlarında dine karşı yapılan kampanya sonucunda 400'e yakın mescidin kapatıldığı hatta bazı uyezdler (kazalar) arasında rekabet yapılırcasına, hangi uyezd daha çok mescit ve kilise kapatacak yarışmasına girildiği, şeriat mahkemeleri kaldırılarak onların yerine Sovyet mahkeme sisteminin getirildiği, komsomolcular (komünist sovyet gençliği) tarafından din adamlarının dövüldüğü" kaydedilmişti. ${ }^{32}$

Çarşafın Atılması, Dinle Mücadele ve Başka Alanlarda AK(b) P’nin Görevleri" isimli belgeden de görüldüğü üzere Bolşevik Partisi önderlerinin uydurduğu "köylülerin mescitlerin kapatılmasına gönüllü olarak onay verdikleri" yalanı, esassızdır. Nitekim Haziran 1929 tarihli belgede bu durum şöyle ifade edilmiştir; "Köy toplantılarında mescitlerin kapatılması ile ilişkili kararın 'köylüler tarafından topyekun alındığı" yalanından bahsetmeye değmez . Çünkü birçoğu fanatik ve gerici olan Türk köylüleri resmî baskı olmadan mescitleri vermeye razı

\footnotetext{
"Bakı Üniversitesi" Neşriyatı, 2012, s. 383.

${ }^{28}$ Memmedov, a.g.e., s. 383.

${ }^{29}$ Y. Baberovskiy, Vrag yest vezde. Stalinizm na Kavkaze. Moskva, Rossiyskaya polit.

Entsklopediya, 2010, s. 581-583.

${ }^{30}$ Hosking , a.g.e., s.127.

${ }^{31}$ AMEA, a.g.e., s. 355.

${ }^{32}$ Svyatoçovskiy, a.g.e., s. 158.
}

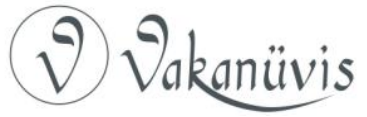


olmuyorlardı."33

Devlet tarafından, dinî inançların, Sovyet hükûmeti düşmanlarının son dayanağı olduğu propagandası yapılıyordu. 1927 yılında UK (b) P MK Teşkilat bürosunun "Müslüman Dinî ile Mücadele Tedbirleri Hakkında" verdiği kararda , dinî okullar için yapılan yeni binaların inşasına engel olmak, yeni dinî kadroların yetiştirilmesini kısıtlamak için hazırlık kurslarının sayısını azaltmak , dinî hedef alan , yerel dillerde basılan toplumsal siyasî eser sayısını çoğaltmak ve gerektiğinde tehlike arz eden şahıslara karşı Devlet Siyasi İdaresi veya i̇ç İşleri Halk Komiserliği tarafından ciddi önlemler almak gibi tedbirler alınması planlanmıştı $^{34}$ Tüm Sovyetler Birliği'nde olduğu gibi Azerbaycan genelinde de din adamlarının takibine ve hapsedilmesine başlanmıştı. Hapse atılan din adamları, halkın veya "işçi-köylü hükûmetinin çıkardığı kanun ve kararlara karşı koymakla" suçlanmışlardı. Sovyet terörüne maruz kalanlar arasında Kuran-ı Kerim'i Azerbaycan Türkçesine ilk çevirenlerden biri, 83 yaşındaki Bakü kadısı Mir Mehemmed Kerimağa da vardı. O da Nargin adasında kurşuna dizilerek öldürülmüştü. ${ }^{35}$

Fakat Sovyet yönetiminin tüm çabalarına rağmen Azerbaycan halkını "Allahsızlaştırmak" mümkün olmadı. Hatta komsomolcuların içinde bile İslami kurallarla yaşayanlar yok değildi. Komsomol MK'nin (Komünist Sovyet Gençliği Merkezi Komitesi) 1929 yılında "Köylerde Komsomol Faaliyetin Durumu Hakkında" adlı raporunda "Bazı komsomolcular mescitlere gidiyor, namaz kılıyor ve diğer dinî vecibeleri yerine getiriyorlar. Zakatala kazasında bir köyün komsomol derneğinin kontrolü sırasında tüm dernek üyelerinin mescitte olduğunun belirlendiği, Nuha kazasında ise 7 komsomolcunun göğsünde "La ilahe" dövmesinin tespit edildiğini" ${ }^{36}$ dile getirmiştir. Müsavat Partisinin önemli fikir adamlarından Mirzebala Memmedzade İstanbul'da basılan "Ateşli Yurt" dergisinde "Allahsızlık uydurularak millî ruhu öldürmek mümkün müdür? Eğer komünistler böyle umuyorlarsa bence yanılıyorlar" ${ }^{\prime 37}$ diye yazmıştı.

\footnotetext{
${ }^{33}$ Refiyev, a.g.e., s. 42.

${ }^{34}$ Gatagova, a.g.e., s.501.

${ }^{35}$ AMEA, a.g.e., s. 358.

${ }^{36}$ ARPii SSA, f. 1, siy.74, iş. 285, v. 32.

${ }^{37}$ ARPii SSA, f.1, siy. 74 , iş. 285 , v. $43-44$.
}

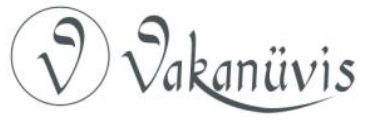


Bolşevikler dinî bayram ve ayinlere karşı da olumsuz tutum takınmışlardı. Örneğin; Ramazan Bayramı'nın işçilerin "sosyalist kuruculuğa aktif katılımına engel olduğu" vurgulanmış, zekat verilmesi yasaklanmıştı. Rejim uyguladığı kurallarla hac ibadetini yerine getirmek isteyen Müslümanların Mekke'yi ziyaretlerini de sınırlamış, 1935 yılında Mekke ziyareti resmen yasaklamıştı. ${ }^{38}$ Yine benzer şekilde Nevruz kutlamaları da yasaklanarak Kurban Bayram'ı aleyhine geniş propagandalar yapılmaya başlanmıştı.

Muharrem ayında yapılan ritüelleri engellemek için de rejim önlemler almıştı. AK (b) P MK ve HKS tarafından Aşure merasiminin yapılmaması için "Defolsun dinî hurafe ve asrın esareti !" sloganı ile biten duyuru ilan edilmişti. ${ }^{39}$ Mayıs 1930' da ise dinî gösteriler , yürüyüşler ve dinî inançlar gereği yapılan fiziksel işkencelerin (zincirle kendine vurma, göğsüne ve dizlerine vurma gibi) yasaklanması ile ilgili karar kabul edilmişti. ${ }^{40}$ Kabul edilen kararlar uygulanırken işçi sınıfının sağlığının korunması, toplumsal huzurun sağlanması mazeret olarak gösterilmiştir.

1928 'in sonu 1929 'un başlarında Azerbaycan köylerinde sosyalizm kuruculuğu için hiçbir zararı olmayan yerel kıyafetler, papak ve çarşafa karşı da "devrim mücadelesi" başlatılmıştır. Komsomolcuların 1929 yılında "Defolsun papak" sloganı ile destekledikleri eylemler neticesinde birçok köylü ve öğrencinin papakları zorla başlarından çıkartılarak yakılmıştı. ${ }^{41}$

Bolşevikler, papak dışında çarşafa karşı da "devrim" başlatmışlardı. Komsomolcular sokaklarda çarşaflı kadınlara saldırarak çarşaflarını çıkartmış, ayaklar altına almışlardı. Bu tür saldırılara karşı ülkenin Gence, Lenkeran, Karyagin (şimdiki Fizuli) ve Bakü bölgelerinde vatandaş ve din adamlarının katıldığı mitingler düzenlenmişti . Hatta siyasî organların hazırladığı bazı gizli belgelerde çarşafin kaldırılması ile ilgili verilen kararın yanlışlığından bahsedilerek işlerin daha da karmaşık

\footnotetext{
${ }^{38}$ Hosking, a.g.e., s. 227-228.

${ }^{39}$ F. İbrahimli, Azerbaycan Kendinde Sosyal-Siyasi Rrosesler (1920-1930). Bakı, 2007 s. 119.

${ }^{40}$ ARPii SSA, f. 1, siy. 74, iş. 300, v. 159.

41 ibrahimli, a.g.e., s. 123.
} 
hale geldiği ifade edilmiştir. ${ }^{42}$ Fakat yerel siyasî idareler tarafindan rapor edilen bu tür bilgileri dikkate almayan rejim, halkın itirazlarını anti Sovyet davranışlar olarak nitelendirmiş ve halk ayaklanmalarına karşı sert tedbirler almayı tercih etmişti. Ülke genelinde devletin uyguladığı yanlış politikaya karşı ayaklanan binlerce insandan sadece Nahçıvan'da 1930 yılının Eylül ayında 51 kişi kurşuna dizilmiş, 38 kişi ise hapsedilmişti. ${ }^{43}$

Dil, alfabe, dinîmerasim ve bayramlara , din adamlarına karşı başlatılan mücadele sırasında halkın âdet ve gelenekleri hiçe sayılmış , geleneksel kurallara saygısızlık yapılmıştı. Fakat bu tür yıkıcı faaliyetlerin çoğalması ve millî değerlere karşı yapılan saygısızlık halkın iradesini kıramamış aksine güçlendirmişti. Devlet dairelerinin, eğitim sisteminin ve soyadlarının Ruslaştırılması, Latin alfabesinden Kiril alfabesine geçilmesi ve buna benzer diğer Sovyet sömürge faaliyetleri halk ve ülke aydınları tarafından itirazlarla karşılanmıştı. Fakat Sovyet Rusya bu itirazları "karşı koyma", "pantürkizm" ve "panislamizm" gibi "zararlı" faaliyetler olarak nitelendirmiş ve binlerce insanı sovyet terörüne kurban etmişti.

\section{Sonuç}

Lenin 24 Mayıs 1917'de "Rusya Halkları Beyannamesi"nde; Rusya Türk ve Müslümanlarına dinî , millî, kültürel özgürlük vaat ederek, tüm haklarının Sovyetler tarafından korunacağından bahsetmişti. Fakat daha sonraki uygulamalar Lenin'in amacının, sadece bu halkların desteğini almak ve Rusya'nın bütünlüğünü korumak için zaman kazanmaktan ibaret olduğunu ortaya koymuştur. Varlığını garanti altına aldıktan sonra Sovyet Rusya mirasçısı olduğu Çarlık Rusya'nın emellerini devam ettirmekten geri kalmamıştı. Aslında Türkler açısından sadece devletin adı değişmiş fakat yöntem ve idarede hiçbir farklılık olmamıştı. Sovyetler devrinde de uzun süren zulümler ve Rus kültürünü Türklere benimsetme çalışmaları yoğunlaşmış, Rusya'nın geleneksel egemenlik politikasına sadık kalınarak Rusya'dan kopan milletleri tekrar zorla Rus egemenliğine katma süreci başlamıştı.

\footnotetext{
${ }^{42}$ Memmedov, a.g.e., s. 385.

${ }^{43}$ Memmedov, a.g.e., s. 386.
}

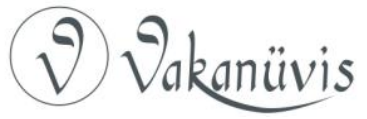


Çarlık Rusya zamanındaki uygulamalardan farklı olarak din yasaklanmış, ibadet mekânları kapatılmış, milletlerin inanç ve ibadet özgürlüklerine karşı baskı yapılmıştı. Çarlık Rusya devrinde olduğu gibi Bolşevik intilali'nden sonra da Azerbaycan'da Rus nüfusun sayısını arttırmak amacı ile Rusların yoğun şekilde ülkeye yerleştirilmesine devam edilmiş, Lenin'in bütün halklara vaat ettiği "eşitlik", "barış" ilkeleri çoktan unutulmuş, Polit Büro'da, Yüksek Sovyet'te ve KGB'nin (Devlet Güvenlik Komitesi) üst düzey idari birimlerinde Ruslar ön plana çıkarılmış, "Sovyetleşme" adı altında "Ruslaştırma" politikası kuvvetlendirilmişti. Bu politika özellikle Stalin döneminde altın çağını yaşamış, devlet politikası olarak benimsenmişti. $\mathrm{Bu}$ dönemde Azerbaycan Türkleri ile ilgili politikalar, ayrı bir önem taşımaktaydı. Bunun nedeni de XX. yüzyılın başlarında Avrupa'da eğitim görmüş, milli kimliğinin farkında olan, ulusal burjuvaziyi oluşturmuş Azerbaycan'ın, Sovyet Rusya sömürge politikasına karşı tehlike oluşturmasıydı. Sovyet rejimi, Azerbaycan'daki millî kimlik farkındalığını yok etmek için 1930'lu yılların sonuna dek kendini Türk olarak tanımlayan milletin bu yıllardan sonra nüfus cüzdanına uydurma "Azerbaycanlı" kimliğin yazdırmıştı.

Stalin'in "Pantürkist" damgası ile damgaladığı Azerbaycan aydınlarının acı sonu, ya infaz ya da Sibirya'daki dondurucu hapishane duvarları olmuştu. Bu aydınların eserleri sakıncalı bulunarak yasaklanmış, yakılmıştı. Özellikle 1937 'de Sovyet Rus politikasına feda edilen Mikail Müşfig, Ahmed Cavad, İstanbul Üniversitesi mezunu Hüseyin Cavid bu kurbanlardan bazılarıydı. Sürülmeyen ve öldürülmeyen diğer aydınlar ise, yoğun şekilde KGB'nin takibine maruz kalmış ve rejimin çıkarları doğrultusunda faaliyet göstermeye mecbur edilmişlerdi.

Maalesef Rus sömürge sistemi, Azerbaycan'da, Rusça konuşmayı aydın olmanın gereği sayan, kendini ana dilinde ifade edemeyen aydın kesim ve gençlik yetiştirmeyi başarmıştır. Rusça bilmeyenler aşağılanarak yetenekli olsalar bile devlet idari makamlarında işe alınmamışlardır. İdarecilikte daha çok Rusça eğitim almış , Komünist ideolojisi ile yetiştirilmiş insanlar tercih edilmiştir. Azerbaycan gençleri askerî hizmet için Rusya'ya gönderilmiş , onlara askeri eğitim yüzeysel verilerek daha çok inşaat ve mutfak işleri yaptırılmıştır.

Azerbaycan'daki zengin petrol ve doğal gaz madenleri dikkate

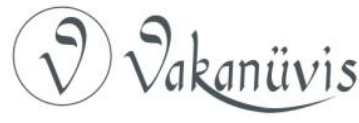


alınarak bölgeye Rus asimile etme politikasının yöntemlerinden biri olan "Rus kadın işçi göçü" gerçekleştirilmiş, Rus kadınlarla evlilikler desteklenmiş, böylelikle de genç erkek nüfusun istihdamı sağlanmayarak, Rusya'ya göçe zorlanmıştır. Bu da özellikle köylerde işgücünün eksikliği, nüfus sayısında azalma gibi olumsuz sonuçlar doğurmuştur. Rusya'da çalışma fırsatı bulan gençler Rus kadınlarla evlenerek kendi örf ve geleneklerinden uzaklaşarak hayatlarını sürdürmek zorunda kalmışlardır.

Sovyet Rusya, Azerbaycan'a egemen olunca kültürel bağı koparabilmek için Türkiye ile ilişkileri yasaklamıştır. Kiril alfabesi zorunlu kılınarak Türklerin birbirinden tamamen koparılması amaçlanmış, bunun için Sovyet eğitimi zorunlu kılınmış, Rusça egemen dil haline getirilmiştir. Görüldüğü gibi, Sovyet rejiminin tüm alanlarda uygulamaya koyduğu asimilasyon ve sömürgeleştirme politikası zaman zaman yerli komünistlerin desteğini de almış, Azerbaycan Türklerinin dil, kültür ve tarihî gerçeklikler saptırılarak tarihinden uzaklaştırılmasına çalışılmış ve bu süreç Sovyetler Birliği'nin dağılmasına kadar devam etmiştir.

\section{KISALTMALAR}

MK: Merkezi Komite

AK (b) P MK: Azerbaycan Komünist (Bolşevik) Partisi Merkezi Komitesi

HKS: Halk Komiserleri Sovyeti

Komsomol: Komünist Sovyet Gençliği

Komsomol MK: Komünist Sovyet Gençliği Merkezi Komitesi

KGB: Devlet Güvenlik Komitesi

SSCB: Sovyet Sosyalist Cumhuriyetler Birliği

UK (b)P MK: Umumittifak Komünist (Bolşevik) Partisi Merkezi Komitesi

\section{KAYNAKÇA}

\section{Arşiv Belgeleri}

Azerbaycan Cumhuriyeti Devlet Başkanı Çalışma Dairesi Siyasi Belgeler Arşivi,f.l, lis.74, dos.285,b.32.

ACDBÇD SBA,f.l,lis.74, dos.300,b.159.

ACDBÇD SBA f.l,lis. 74,dos. 283,b.186

ACDBÇD SBA,f.l,lis.74,dos.282,b.138.

ACDBÇD SBA, f.l,lis.74,dos.321,b.106-107.

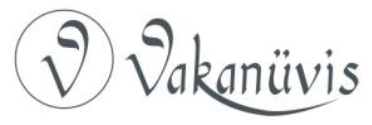




\section{Araştırma Eserler}

Aslan,Yasin, "Üçüncü Roma'nın Jeopolitik Arzuları", Avrasya Uluslararası iliş̧iler ve Araştırma Merkezi, Ankara, 1995.

Baberovskiy,Y., Vrag yest vezde. Stalinizm na Kavkaze. Rossiyskaya polit. Entsklopediya, Moskva, 2010.

Hasanov, C., Beyaz Lekelerin Kara Gölgesi, "Gençlik", Bakü, 1991.

Hosking, Djeffri, istoriya Sovetskovo Soyuza (1917-1991) / Perevod c angl.

P.Kutsenkova., "Rusiç", Smolensk, 2000.

İbrahimli, F. Azerbaycan Köyünde Toplumsal Siyasi Süreçler (1920- 1930), Mütercim, Bakü, 2001.

Koctırçenko, G.V., Taynaya Politika Stalina: Vlast i Antisemitism. İzd. 2-oe, Mejdunarodnıye Otnoşeniya, Moskva, 2003.

Memmmedzade, M.B., Köylü Herekatı Lenin Milli Siyaseti., Azerneşr, Bakü, 1995.

Memmedov, Nuru Zeynalabdin oğlu, Azerbaycan Devletçiliği Tarihinde Azerbaycan Merkezi Icraiyye Komitesinin Yeri ve Rolu (1921-1938),"Bakı Universiteti" neşriyatı, Bakü, 2012.

Refiyev, B. , Aysbergin Sualtı Bölmesi., Azerneşr, Bakü, 1995.

Svyatoçovskiy,T., Rusya ve Azerbaycan: Sınır Bölgesi Geçit Devrinde (Ingilizceden çeviri), Hazar Üniversitesi Matbaası, Bakü, 2000.

Azerbaycan Tarihi (aprel 1920 -iyun 1941)VI.cilt, Azerbaycan Milli Elmler Akademiyası A.Bakıhanov Adına, Tarih Institutu Yayınları, Elm,Bakı, 2008.

TSK RKP(b) i Natsionalnıy Vopros. Kniga 1. 1918-1933 gg. / Sostaviteli L.S. Gatagova, L.P. Koşeleva, L.A. Rogovaya. Moskva,2005.

1926 Yılı I. Bakü Türkoloji Kurultayı, "Çınar-Çap" Matbaası, Bakü, 2006. VIII Syezd Azerbaydjanskoy Kommunistiçeskoy Partii. 12-18.XI.1927g. 


\section{EKLER:}

\section{EK.1}

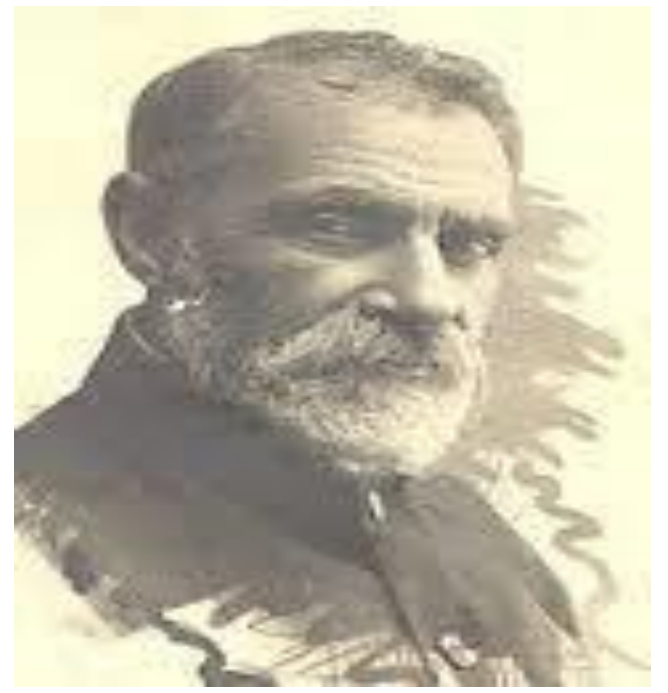

\section{Samed Ağa Ağamalığlu}

\section{EK. 2}

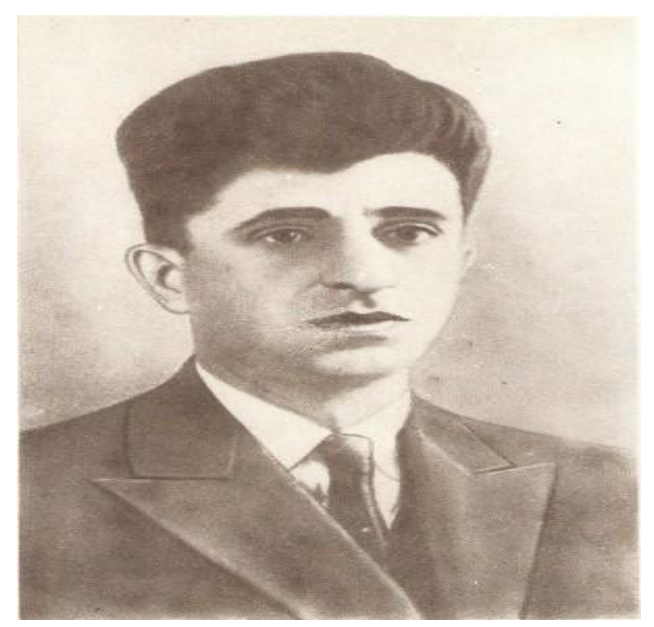

Ruhullah Ahundov

$$
\text { (D) Vakanüvis }
$$




\section{EK 3}

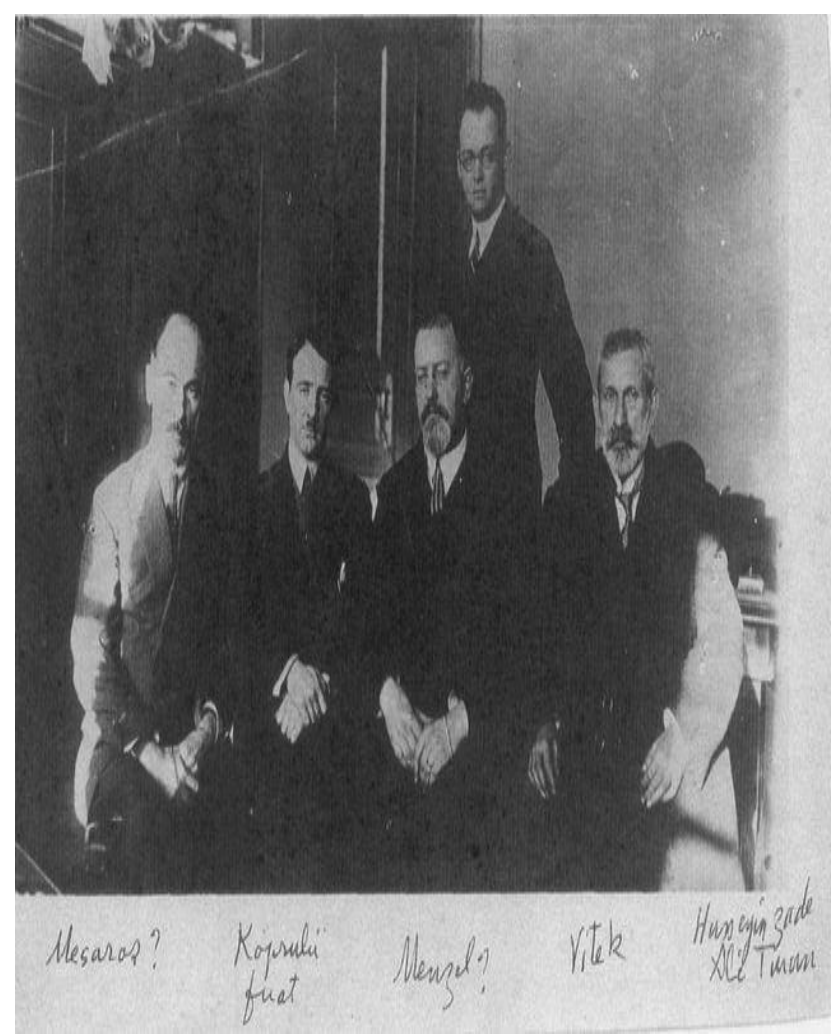

Bakü Türkoloji Kurultayı katılımcılarından bazıları

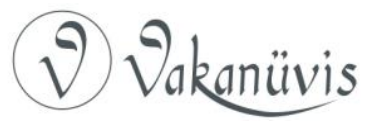

